\title{
JWANENG FRAMESITES - INCLUSIONS AND CARBON ISOTOPES.
}

Kirkley, M.B.; Gurney, J.J. and Rickard, R.S.

Geochem. Dept., Univ. Cape Town, Rondebosch 7700, South Africa.

The highly diamondiferous Jwaneng kimberlite diatreme in Botswana, like orapa, produces numerous examples of polycrystalline diamond aggregate, known as framesite. Carbon isotope compositions have been determined and clinopyroxene, chromite, and garnet have been identified as inclusions in a small sample suite of Jwaneng framesite (JWf). The inclusions have unusual major element compositions (Table 1) compared to inclusions in single crystal diamonds from Jwaneng and in diamonds worldwide.

Carbon Isotopes The Jwf samples studied exhibit a bimodal distribution of $\delta{ }^{3} \mathrm{CPB}$ values with peaks at approximately -19 and $-2 \% 00$ (Fig. 1). The framesites appear to be isotopically homogeneous with a maximum difference of 0.50 \% 0 being detected among fragments of individual samples. No $\delta^{13} \mathrm{C}$ values have yet been found which correspond to the prominent peak in the range -3 to $-90 / 00$ developed by peridotitic diamonds worldwide.

Clinopyroxene A clinopyroxene (cpx) inclusion which coexists with chromite in JWF4 contains a high proportion of the ureyite molecule $\left(34 \% \mathrm{NaCrSi}_{2} \mathrm{O}_{6}\right)$. $\mathrm{K}_{2} \mathrm{O}$ content is $0.09 \mathrm{wt}$. The cpx is similar in composition (Fig. 2) to cpx in framesites from Orapa (10.24 wt\% $\mathrm{Cr}_{2} \mathrm{O}_{3}$; Gurney and Boyd, 1982) and from Mir (11.8 wt.\% $\mathrm{Cr}_{2} \mathrm{O}_{3}$; Sobolev, et al., 1971).

Chromite Jwf chromites are particularly high in $\mathrm{Cr}_{2} \mathrm{O}_{3}$ and low in Mgo compared to other chromites closely associated with diamond (Fig. 3). Up to 0.3 wt\% $\mathrm{ZnO}$ has been detected. The Jwf chromites occur as subhedral crystals embedded in a white alteration product, largely carbonate, which commonly fills vugs and forms coats on Jwf.

Garnet. Garnet in JWFIl is intermediate between eclogitic and peridotitic inclusions in Jwaneng single crystal diamonds with respect to $\mathrm{Cr}_{2} \mathrm{O}_{3}, \mathrm{CaO}$ and $\mathrm{MgO}$ ( $\left.\mathrm{Fig} .4\right) . \mathrm{TiO}_{2}(0.5$ wt\%) and $\mathrm{Na}_{2} \mathrm{O}(0.1 \mathrm{wt} \%)$ contents are, in contrast, typical of eclogitic diamonds.

$\delta^{13} \mathrm{C}$ values and inclusion compositions indicate that Jwaneng framesites have an eclogitic affinity. That this eclogitic association is a product of subduction of crustal rocks is supported by the presence of ureyitic clinopyroxene ( $8.4 \mathrm{wt} \% \mathrm{Cr}_{2} \mathrm{O}_{3}$ ) in omphacite xenoliths from the Colorado Plateau diatremes which are considered to represent subducted chromite-bearing basalts or clinopyroxenites metasomatized by Na-bearing fluids (Helmstaedt and Schulze, 1988).

\section{REFERENCES}

Gurney, J.J., and Boyd, F.R. (1982) Mineral intergrowths with polycrystalline diamonds from the Orapa Mine, Botswana. Carnegie Institute of Washington Geophysical Laboratory, Annual Report of the Director, 1981-1982, p. 267-273.

Helmstaedt, H., and Schulze, D.J.' (1988) Eclógite-facies ultramafic xenoliths from Colorado Plateau diatreme breccias. In D.C. Smith, Ed., Eclogites and eclogite facies rocks, p. 287-450. Elsevier, Amsterdam.

Sobolev, N.V., Botkunov, A.I. , Lavrent'yev, Yu.G., and Pospelova', L.N. (1971) Péculiarities of the composition of minerals coexisting with diamond from Mir. Zapiski Vsesoyuznyi Mineralogia Obshchestva, 100,558-564 (in Russian). 
Table 1. Jwaneng framesite inclusion compositions.

\begin{tabular}{|c|c|c|c|c|}
\hline & & 4 & JWF 5 & JWF 11 \\
\hline & $\delta^{13} \mathrm{C}$ & $-1 \cdot 3$ & $\delta^{13} \mathrm{C} \quad-1.3$ & $\delta^{13} c-18.8$ \\
\hline & CPX & CHR & CHR & GAR \\
\hline $\mathrm{iOO}_{2}$ & 54.28 & 0 & 0 & 42.21 \\
\hline $\mathrm{TiO}_{2}$ & 0.09 & 0.16 & 0.15 & 0.55 \\
\hline $\mathrm{Al}_{2} \mathrm{O}_{3}$ & 3.68 & 3.23 & 3.43 & 20.77 \\
\hline $\mathrm{Cr}_{2} \mathrm{O}_{3}$ & 11.56 & 69.51 & 69.60 & 3.89 \\
\hline $\mathrm{FeO}$ & 1.80 & 15.95 & 15.22 & 7.50 \\
\hline Mno & 0 & 0.32 & 0.33 & 0.37 \\
\hline MgO & 9.78 & 7.47 & 8.28 & 20.84 \\
\hline $\mathrm{CaO}$ & 10.63 & - & - & 3.75 \\
\hline $\mathrm{Na}_{2} \mathrm{O}$ & 7.21 & - & - & 0.13 \\
\hline $\mathrm{K}_{2} \mathrm{O}$ & 0 & - & - & - \\
\hline TOTAL & 99.02 & 96.64 & 97.01 & 100.01 \\
\hline OXY & 6 & 4 & 4 & 12 \\
\hline $\mathrm{Si}$ & 1.997 & 0 & 0 & 3.008 \\
\hline $\mathrm{Ti}$ & 0.002 & 0.004 & 0.004 & 0.029 \\
\hline Al & 0.159 & 0.135 & 0.142 & 1.745 \\
\hline $\mathrm{Cr}$ & 0.336 & 1.943 & 1.927 & 0.219 \\
\hline $\mathrm{Fe}$ & 0.055 & 0.472 & 0.446 & 0.447 \\
\hline Mn & 0 & 0.010 & 0.010 & 0.022 \\
\hline Mg & 0.536 & 0.394 & 0.423 & 2.214 \\
\hline $\mathrm{Ca}$ & 0.419 & - & - & 0.286 \\
\hline $\mathrm{Na}$ & 0.514 & - & - & 0.018 \\
\hline $\mathrm{K}$ & 0 & - & - & - \\
\hline SUM & 4.020 & 2.958 & 2.961 & 7.989 \\
\hline
\end{tabular}

Figure 1. Carbon isotope compositions of Jwaneng framesites.

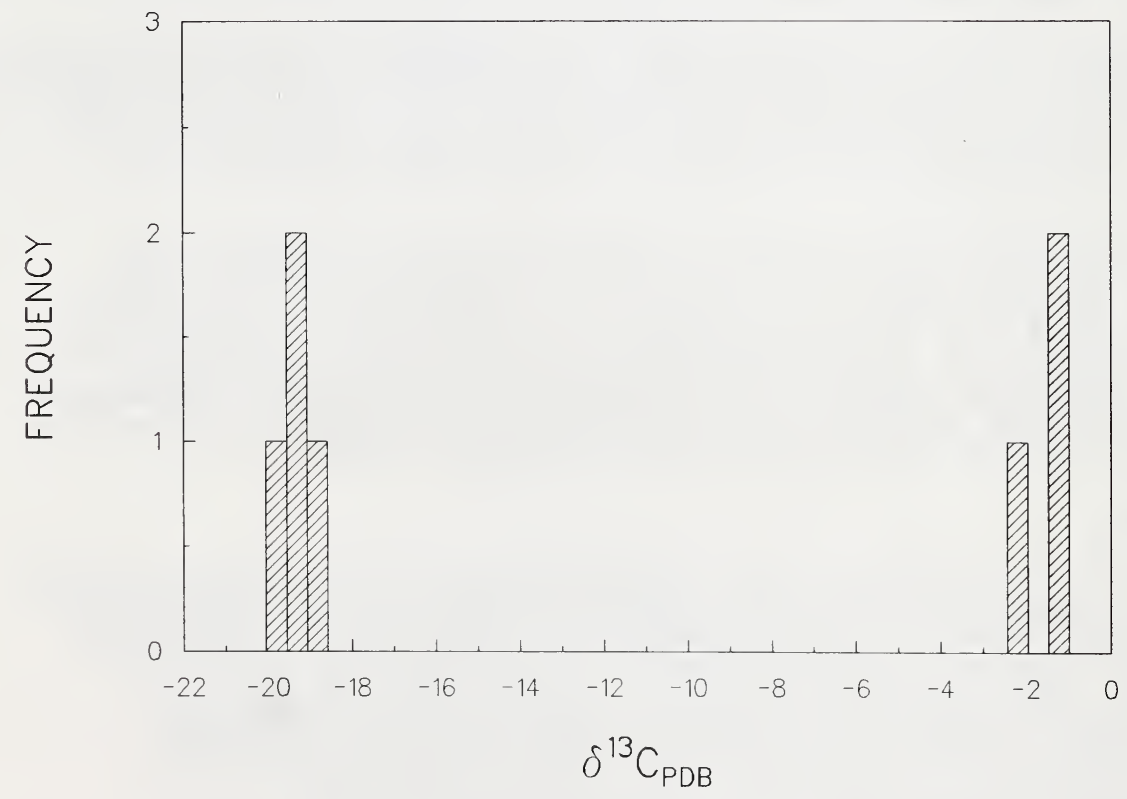


Figure 2. Jwaneng clinopyroxene inclusions.

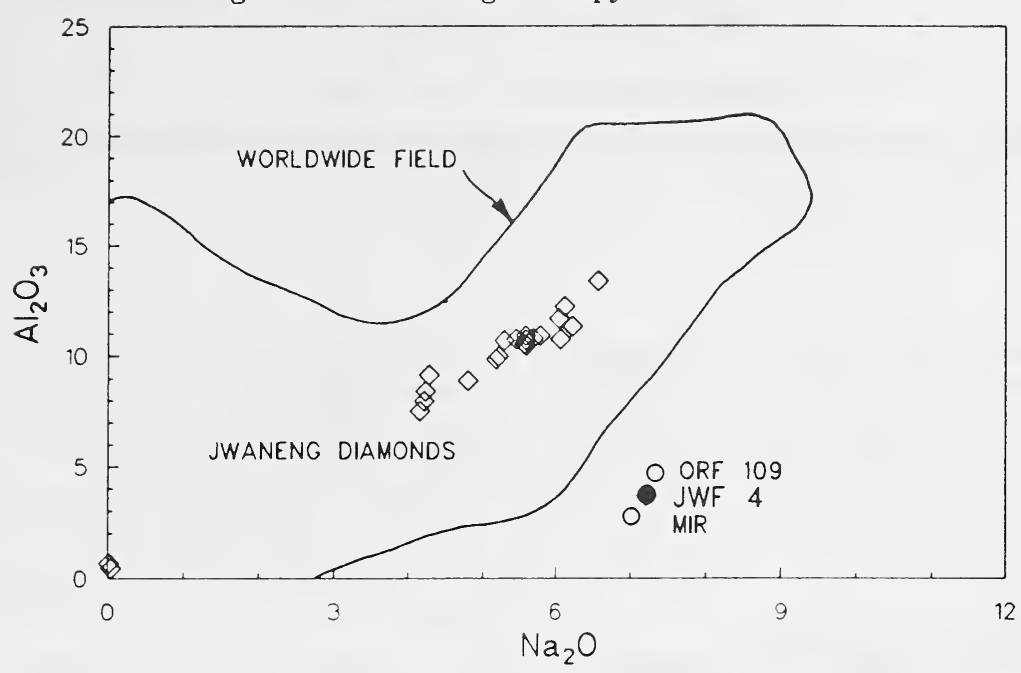

Figure 3. Jwaneng chromite inclusions

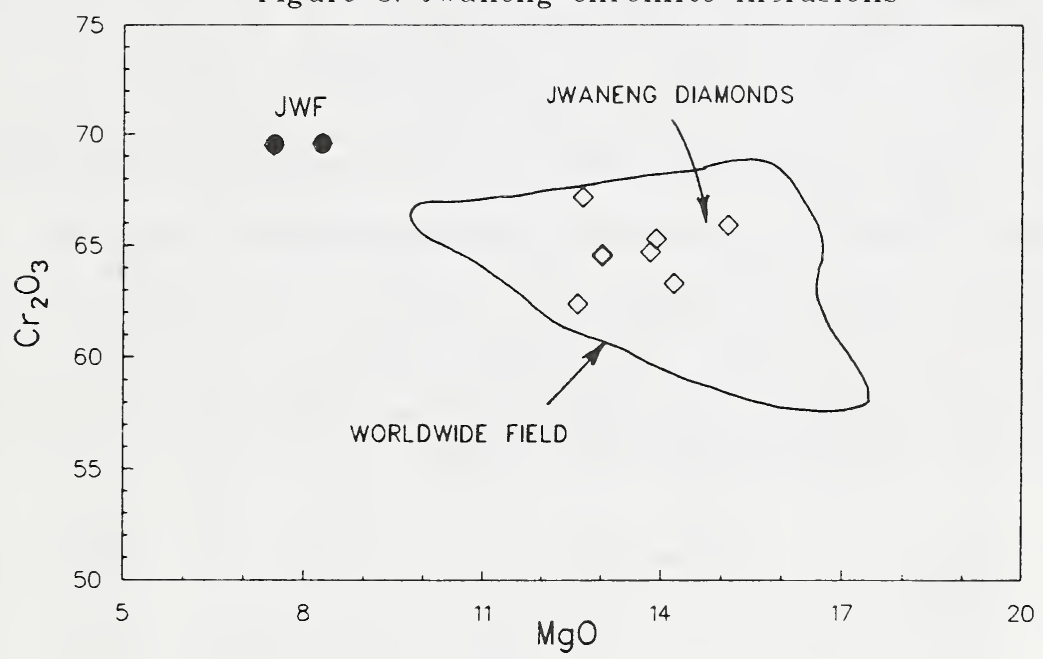

Figure 4. Jwaneng garnet inclusions.

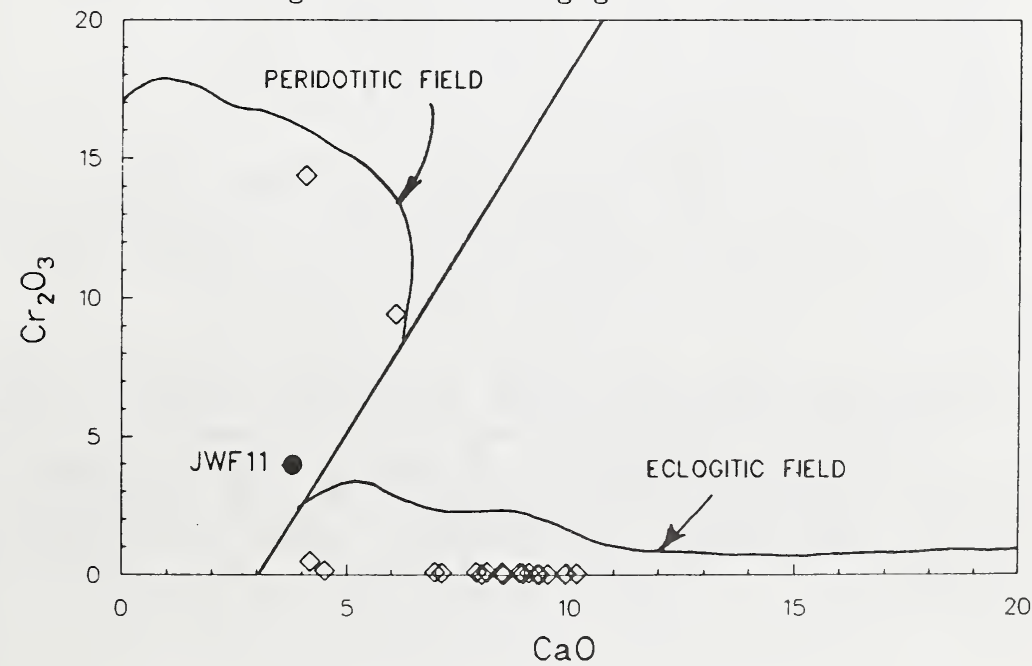

